ANUVA Volume 2 (1): 29-42, 2018

Copyright (C2018, ISSN: 2598-3040 online

Available Online at: http://ejournal.undip.ac.id/index.php/anuva

\title{
Analisis Penyebaran Informasi Pada Sosial Media
}

\author{
Yuli Rohmiyati ${ }^{* *}$ \\ ${ }^{I}$ Prodi Ilmu Perpustakaan, Fakultas Ilmu Budaya, Universitas Diponegoro \\ Jl. Prof. Soedarto, SH, Kampus Tembalang, Semarang. Indonesia \\ *)Korespondensi : yulirohmiyati@gmail.com
}

\begin{abstract}
The purpose of this study is to analyze the dissemination of information on social media, especially facebook. The research method used is descriptive research method with observation data collection techniques on various opinions that appear on social media facebook. The results can be seen that the dissemination of information on social media will be more dominant if more and more social media argue the dominant opinion among the community then the fading or weaker opinions in the community who oppose the dominant opinion.
\end{abstract}

Keywords: social media, information dissemination, radicalism

\begin{abstract}
Abstrak
Tujuan dari penelitian ini adalah menganalisis penyebaran informasi pada media sosial terutama facebook. Metode penelitian yang dipakai adalah metode penelitian deskriptif dengan teknik pengumpulan data observasi pada berbagai opini yang muncul pada media sosial facebook. Hasil penelitian dapat diketahui bahwa penyebaran informasi pada media sosial akan semakin dominan jika semakin sering media sosial mengemukakan pendapat yang dominan di kalangan masyarakat maka semakin memudar atau melemah pendapat-pendapat di kalangan masyarakat yang menentang pendapat dominan.
\end{abstract}

Kata kunci: media sosial, penyebaran informasi, radikalisme

\section{Pendahuluan}

Sejarah mendeskripsikan bahwa media massa memiliki kekuatan dan memberikan pengaruh persuasif yang masif pada publik sebab media massa terbukti berpengaruh telah melakukan brainwash selama Perang Dunia berlangsung dan menjadi mesin efektif bagi penyebaran ideologi fasisme di Eropa selama masa perang (Curran, 2000), sehingga tidak mengherankan jika media massa disebut-sebut ikut andil dalam menyebarkan paham atau ideologi yang berpengaruh signifikan terhadap konstruksi dunia di masa itu. Media massa adalah perpanjangan alat indera kita dalam memperoleh informasi tentang benda, orang, atau tempat yang tidak alami secara langsung. Pengaruh media massa terasa lebih kuat lagi, karena pada masyarakat modern orang banyak memperoleh informasi tentang dunia dari media massa yang terhubung dengan internet. Menurut Wilbur Schram (Rakhmat, 2004 : 208) Media massa memenuhi kebutuhan fantasi dan informasi, hiburan dan informasi yang diinginkan semua orang.

Seiring dengan perkembangannya, media massa dengan dukungan internet mampu melahirkan suatu jaringan baru yang biasa dikenal dengan sebutan media sosial. Munculnya internet 
yang hampir di seluruh belahan dunia merupakan sebuah fenomena yang kehadiran media sosial telah membawa pengaruh tersendiri terhadap kegiatan yang dilakukan oleh manusia saat ini. Sebagaimana yang diketahui, media sosial merupakan salah satu media online dimana para penggunanya dapat ikut serta dalam mencari informasi, berkomunikasi, dan menjaring pertemanan, dengan segala fasilitas dan aplikasi yang dimilikinya seperti Blog, Facebook, Twitter, Instagram, dan lainnya.

Media sosial merupakan alat komunikasi yang populer saat ini. Fungsi media sosial untuk berinteraksi semakin besar, terutama karena kemudahan fasilitasnya dalam menyebarkan informasi. Juga karena informasi yang dapat diakses oleh masyarakat dengan cepat dan terbuka di media sosial tersebut membuat sebagian besar masyarakat Indonesia terperdaya dan terbawa emosi dalam isu yang sedang merebak. Individu dalam masyarakat dengan mudah dapat menyebarkan berbagai hal dari mulai aktifitas pribadi, keluarga, bisnis, politik ataupun mencurahkan permasalah yang sedang dihadapi dalam media sosial.

Media sosial memang banyak memiliki manfaat, namun di sisi lain banyak pula sisi buruknya. Kebenaran informasi dalam media sosial sangatlah sulit diukur, karena informasi yang ada dalam media sosial adalah pendapat pribadi yang sangat subjektif atau bermuatan emosional individu.

Informasi dalam media sosial terkadang berisi hoax, fitnah, desas desus, kabar bohong, ujaran kebencian, aib dan kejelekan seseorang. Informasi pribadi yang diunggah ke publik, dan hal-hal lain sejenis sebagai sarana memperoleh simpati, like, komentar, lahan pekerjaan, sarana provokasi, dan sarana mencari keuntungan politik serta ekonomi dapat menimbulkan gesekan di tengah masyarakat.

Gesekan-gesekan tersebut menjadi lebih meresahkan akhir-akhir ini. Saling serang dan saling sindir di media sosial kemudian menjadi aksi nyata seperti gerakan 212 ataupun gerakan demo etnis. Gerakan-gerakan tersebut mengarah pada sikap ekstrim antar golongan selain itu juga mengarah pada radikalisme di masyarakat. Munculnya fenomena-fenomena tersebut membuat persatuan rapuh dan nilai-nilai kebangsaan kita menjadi luntur. Nilai-nilai ketuhanan, persatuan, keadilan, gotong royong semakin tidak ada pada pribadi-pribadi bangsa Indonesia

Dalam beberapa penelitian yang telah dilakukan ada dua hal yang bisa kita baca sebagai penyebab radikalisme. marjinalisasi politik atau kelompok tertentu. Kedua, fenomena ekonomi-politik bahwa, radikalisme muncul karena ekses kapitalisme yang menciptakan mereka yang tak memiliki akses pada sumber-sumber modal. Dalam bahasa ekonomi-politik, pendekatan ini dikenal dengan "pendekatan kelas". Artinya, respons radikalisme pada dasarnya adalah respons kelas untuk melawan hegemoni kapital yang oligarkis dengan Negara (Umar, 2010)

Faktor-faktor yang mendorong munculnya radikalisme di Indonesia, berdasarkan hasil penelitian ditemukan sekurang-kurangnya ada tiga faktor, yakni pertama, perkembangan di tingkat global, kedua penyebaran paham tertentu dan yang ketiga adalah kemiskinan. Pada saat ini, masuknya faham- 
faham tertentu telah ikut mendorong timbulnya kelompok eksklusif yang sering menuduh orang lain yang berada di luar kelompok mereka sebagai musuh (Asrori, 2012).

Media sosial yang paling banyak digunakan oleh masyarakat Indonesia selama tahun 2016 adalah Facebook. Walaupun berada di peringkat kedua setelah Thailand, namun harus diakui bahwa Indonesia adalah salah satu penyumbang terbesar pengguna Facebook. Tercatat ada 11.658 .760 pengguna Facebook yang berasal dari Indonesia. Pengguna Facebook paling banyak ada pada rentang usia 30-35 tahun ke atas (hasil penelitian Statista). Kemudian diikuti oleh pengguna rentang usia 26-29, 20-25 dan 16-19 tahun. (www.kompasiana.com)

Dari data yang keluarkan oleh Newsroom, pengguna Facebook aktif per 31 Desember 2015 di dunia sebanyak 1, 55 milyar pengguna. Sementara itu dari data yang dilansir petinggi Facebook Indonesia pada tahun 2015 pengguna internet di Indonesia mencapai 88,1 juta jiwa atau 34, $9 \%$ dari total jumlah penduduk Indonesia. Sementara itu $99 \%$ pengguna internet berada dalam jaringan (daring). Pengguna jejaring sosial yang menempati ranking tertinggi adalah Facebook dengan jumlah 78 juta pengguna, kemudian Instagram dan Twitter. Tim Jejak Pendapat App membuat studi prilaku pengguna Facebook mencatat $89 \%$ orang Indonesia secara aktif menggunakan Facebook dalam menjalankan aktivitas seharihari. Rata-rata mereka mengjunjingi akun Facebook 1-6 kali sehari dalam waktu kisaran 3-10 menit. (www.kompasiana.com)

Penelitian ini hendak menganalisis bagaimana peranan media social dalam fenomena radikalisme yang mengatasnamakan agama, ras, etnis, kelompok, dan suku yang kembali marak belakangan ini. Juga akan menganalisis penyebaran informasi dalam social media dapat meningkatkan radikalisme yang mengancam nilai nilai kebangsaan. Radikalisme menjadi bagian dari dinamika sosial itu sendiri sebagai aksi dan reaksi dari anti kemapanan, anti globalisasi, dan simbol kekuatan baru yang anti ekstrim.

\subsection{Rumusan Masalah}

Dari latar belakang yang telah diuraikan, maka rumusan masalah dalam penelitian ini adalah Bagaimana penyebaran informasi dalam sosial media dapat meningkatkan radikalisme yang mengancam nilai nilai kebangsaan?

\subsection{Tujuan Penelitian}

Tujuan yang ingin dicapai dalam penelitian ini adalah untuk mengetahui analisis penyebaran informasi dalam social media dapat meningkatkan radikalisme yang mengancam nilai nilai kebangsaan. 


\subsection{Manfaat Penelitian}

Manfaat penelitian ini adalah:

1. Secara teoretis : Penelitian ini akan menemukan prosentase informasi radikal pada facebook dan analisis penyebaran informasi dalam media sosial.

2. Secara praktis : Mengurangi dampak negatif dari penggunaan dan pemanfaatan teknologi yang mengikis nilai-nilai kebangsaan.

\section{Tinjauan Pustaka}

\subsection{Penyebaran Informasi}

Model penyebaran informasi yang dipakai adalah model spiral keheningan (the spiral of silence) yang dikemukakan oleh Elisabeth Noelle Neumann (1974). Teori ini menjelaskan tentang dampak penyebaran informasi melalui media massa. Menurut model ini, besar kecilnya pengaruh media massa tergantung pada interaksi antara media massa, komunikasi antar pribadi, dan persepsi seseorang mengenai pendapat dirinya dikaitkan dengan dengan pendapat orang lain yang ada di lingkungan masyarakat sekitarnya (lihat gambar 1)

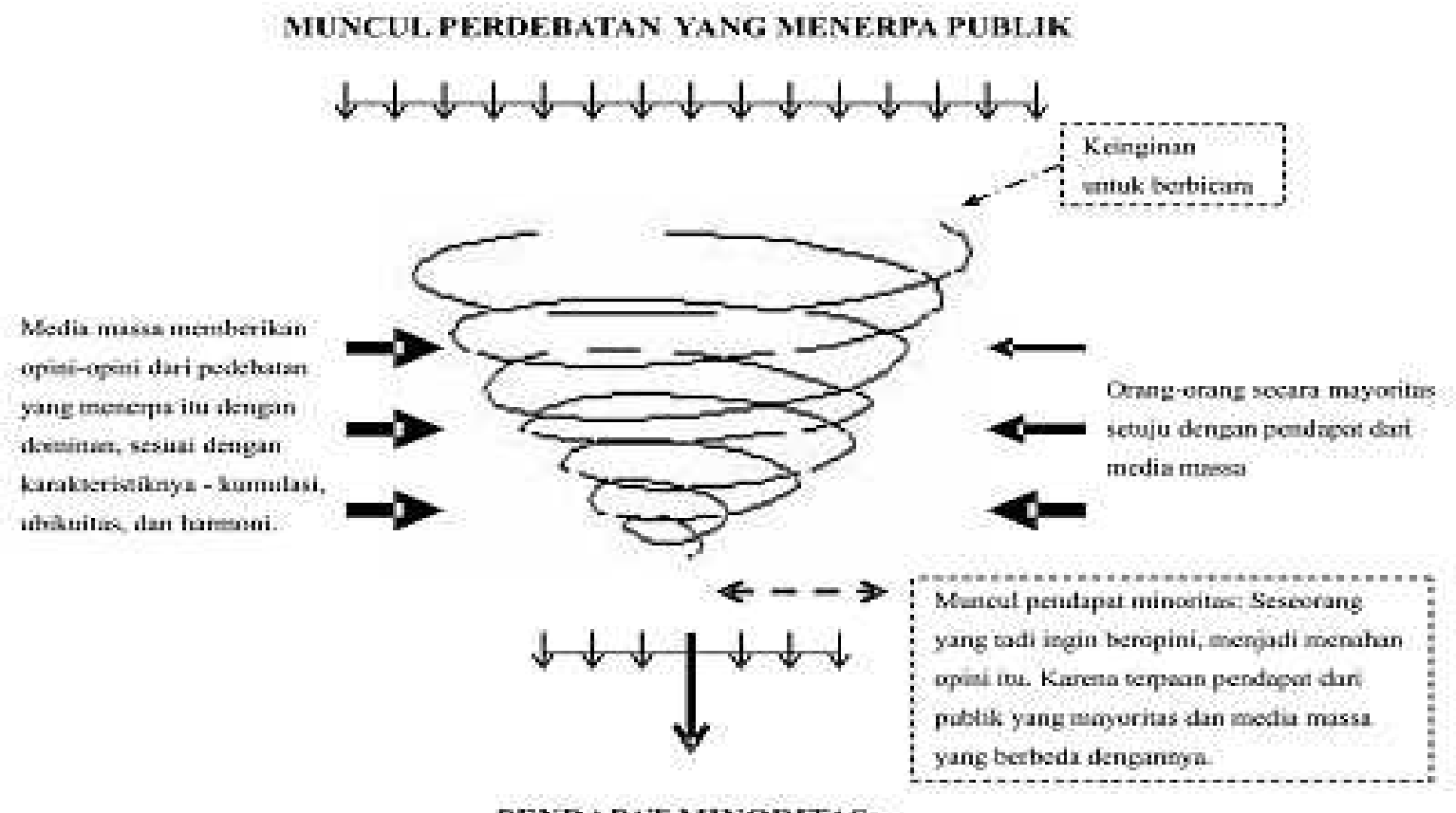

KETAKUTANAKAN TERISOLASI

Gambar 1. Model Spiral Keheningan

(Nuruddin, 2012)

Penjelasan Spiral Keheningan sebagai berikut: Asumsi dari model ini, sebagaimana terlihat dalam gambar di atas, adalah semakin sering media massa mengemukakan pendapat yang dominan di 
kalangan masyarakat, semakin memudar atau melemah pendapat-pendapat di kalangan masyarakat yang menentang pendapat dominan sebagaimana dikemukakan media massa. Jumlah orang yang secara terbuka menentang pendapat dominan yang dikemukakan media massa akan semakin mengecil. Dengan kata lain, suara-suara yang menentang akan semakin hening. Asumsi ini didasarkan pada pertimbangan bahwa pada dasarnya, kebanyakan orang dalam masyarakat cenderung tidak mau mengisolasikan dirinya dari lingkungan masyarakat di sekitarnya. Oleh karena itu, biarpun seseorang punya sikap atau pendapat yang berlainan, ia akan berusaha untuk tidak menentang secara terbuka sikap dan pendapat orang-orang lain di lingkungan sekitarnya (Nurudin, 2012)

\subsection{Media Sosial}

Internet dapat menghubungkan orang dari berbagai belahan dunia baik itu yang belum mengenal atau yang sudah mengenal, baik itu dari suku, rasa atau agama yang berbeda, semuanya dapat berkomunikasi langsung melalui media internet. Sebab di dalam media internet memang banyak sarana pendukung bagi manusia untuk melakukan komunikasi. Seperti yang diungkapkan oleh Tracy (1997: 2) "...internet adalah semacam jagad raya yang terus menerus berkembang memiliki geografi, 'cuaca', dan budaya sendiri. Dalam dunia cyber ini, berbagai orang dalam penjuru dunia berkomunikasi melalui zona waktu yang berbeda tanpa saling bertatap muka, dan informasinya tersedia 24 jam sehari dari ribuan tempat". Salah satu bentuk baru dalam berkomunikasi yang ditawarkan salam dunia internet adalah media sosial. Dengan menggunakan media sosial dalam internet, pengguna bisa meluaskan perkataan ataupun hal yang dia alami. Seperti yang diutarakan oleh Kaplan dan Haenlein (dalam Curran, 2011), media sosial adalah "sebuah kelompok jaringan yang berbasiskan aplikasi dalam internet yang dibangun berdasar teknologi dan konsep web 2.0, sehingga dapat membuat pengguna (users) menciptakan dan mengganti konten yang disebarkan”.

Istilah "web 2.0" digunakan secara khusus untuk menjelaskan teknologi semacam wikis, weblogs, dan media internet lainnya. Web 2.0 penting untuk media sosial karena mampu mempercepat pertumbuhan dari media sosial. Karjaluoto (2008: 2) mengungkapkan bahwa istilah media sosial menggambarkan sebuah media sehingga para pengguna dapat dengan mudah berpartisipasi dan memberi kontribusi di dalam media tersebut. Karakteristik umum yang dimiliki setiap media sosial yaitu adanya keterbukaan dialog antar para pengguna. Media sosial dapat dirubah oleh waktu dan diatur ulang oleh penciptanya, atau dalam beberapa situs tertentu, dapat diubah oleh suatu komunitas. Selain itu media sosial juga menyediakan dan membentuk cara baru dalam berkomunikasi. Seperti diketahui, sebelum muncul dan populernya media sosial, kebanyakan orang berkomunikasi dengan cara sms atau telpon lewat handphone. Namun sekarang dengan adanya media sosial, orang cenderung berkomunikasi lewat layanan obrolan (chat) atau berkirim pesan lewat layanan yang tersedia di media sosial. 
Menurut Karjaluoto (2008: 4), media sosial ada enam macam yaitu: (1). Blog (blogs or web blogs), yaitu sebuah website yang dapat digunakan untuk memasang tulisan, baik oleh satu orang atau kelompok, dan juga 18 menyediakan ruang sehingga pembaca tulisan dapat memberi komentar. Banyak macam-macam blog di dunia, dan blog menjadi popular karena menyediakan perspektif yang utuh dan asli mengenai topik-topik tertentu. (2). Forum (Forums), yaitu sebuah situs dimana beberapa pengguna (users) dapat menyusun topik dan mengomentari topik yang dibuat. Semua orang yang mengunjungi situs tersebut dapat memberikan komentar. Selain itu, biasanya forum ini dijadikan rujukan bagi mereka yang tertarik pada suatu topik. Contoh dari forum yang cukup popular adalah kaskus. Di dalam kaskus terdapat berbagai topik yang diciptakan oleh para pengguna situs atau diusulkan oleh para pengunjung situs tersebut. (3). Komunitas Konten (content communities), yaitu situs yang memungkinkan pengguna (users) untuk memasang atau menyebarkan konten. Konten yang dipasang dan disebarkan biasanya berupa video atau foto untuk bercerita dan berbagi. Beberapa situs ini menyediakan layanan untuk voting, sehingga pengunjung dapat ikut menentukan relevansi konten yang akan dipasang dan disebarkan. (4). Dunia virtual (virtual worlds), merupakan sebuah situs yang menyediakan dunia virtual bagi para pengunjungnya. Yaitu dunia yang seolah-olah nyata, dikarenakan pengunjung bisa saling berinteraksi dengan pengunjung lainnya, namun pada dasarnya dunia tersebut hanya ada di dalam internet. Salah satu contoh yang cukup popular dari dunia virtual adalah situs game on-line. Pengunjung dapat berinteraksi dan berjuang bersama dengan pengunjung lain atau dapat juga bersaing dengan pengunjung lain. (5). Wikis, yaitu situs penghasil data-data atau dokumen-dokumen. Dalam situs ini, pengunjung yang telah diterima sebagai pengguna (users) resmi dapat mengganti atau menambah konten yang ada dalam situs dengan sumber yang lebih baik. Wikipedia merupakan salah satu contoh dari situs wikis. (6). Jejaring Sosial (social networks), yaitu komunitas virtual yang memungkinkan pengguna (users) untuk berkoneksi dengan pengguna (users) yang lainnya. Beberapa situs jejaring sosial dibuat untuk memperluas jaringan kelompok (contohnya Facebook), sementara yang lainnya dibuat berdasarkan wilayah tertentu saja (contohnya Linkedln). Salah satu media sosial yang cukup popular yaitu jejaring sosial. Jejaring sosial merupakan struktur sosial yang terdiri dari elemen-elemen individual atau organisasi. Jejaring ini menunjukan jalan dimana mereka berhubungan karena kesamaan sosialitas, mulai dari mereka yang dikenal sehari-hari sampai dengan keluarga. Situs jejaring sosial juga terdapat beberapa macam, seperti Facebook, My space, atau Friendster.

Facebook merupakan salah satu bentuk jejaring sosial (social networking). Menurut Ford (Juli: 2011), jejaring sosial merupakan sebuah konsep dari struktur sosial yang dibentuk oleh beberapa orang atau organisasi yang dihubungkan oleh satu atau beberapa hubungan khusus -seperti pertalian keluarga, pertemanan, hubungan asmara, pertukaran ekonomi, keyakinan, jabatan, hingga persamaan minat di antara anggota dalam sudut pandang link atau koneksi berbasis internet. Dengan pengertian yang diungkapkan oleh Ford tersbut menjadi jelas bahwa yang dinamakan hubungan yang disebut jejaring sosial adalah sebuah koneksi yang mendasarkan pada jaringan internet. Hubungan sosial 
yang terbentuk dari pertalian keluarga, pertemanan, hubungan asmara, pertukaran ekonomi atau keyakinan atau jabatan, hingga persamaan minat, semuanya termanifestasi dan terjalin melalui dunia internet. Berdasarkan definisi Ford di atas, lebih tepat jika istilah 'koneksi' digunakan untuk menggambarkan atau mewakili hubungan yang dijalin sekelompok individu dalam dunia internet.

Sedangkan menurut Kim dan Lee (2011: 359), situs jejaring sosial adalah sebuah website yang tidak hanya menampilkan daftar koneksi sosial, tetapi juga menyediakan fitur-fitur dimana pengguna (users) dapat menampilkan diri mereka kepada pengguna yang lain. Berdasarkan pendapat dari Kim dan Roselyn ini, di dalam situs jejaring sosial terdapat daftar yang memuat nama-nama atau kelompok dengan mana pengguna menjalin koneksi sosial.

Tapi selain terdapat daftar pertemanan atau koneksi sosial, situs jejaring sosial juga menyediakan fitur-fitur atau layanan dimana pengguna (users) dapat menampilkan profil atau data mengenai pengguna (users) kepada pengguna (users) yang lain. Fitur yang tersedia dalam situs jejaring sosial juga berupa fitur untuk berubah-ubah (update) status, mengatur foto atau video yang diunggah, mengolah pesan dalam situs.

Pendapat lain menurut Boyd dan Ellison (dalam Thelwall, 2009: 22), situs jejaring sosial adalah layanan berbasis Web yang memungkinkan pengguna untuk: 1. Membuat profil terbuka atau semi terbuka dengan sistem yang saling terhubung. 2. Mengatur daftar, dengan siapa saja pengguna akan berbagi koneksi. 3. Melihat dan mengunjungi daftar koneksi miliknya juga milik pengguna yang lain.

Berdasar pendapat Ford, Boyd dan Ellison itu berarti situs jejaring sosial merupakan jaringan sosial pertemanan, percintaan, atau perkumpulan suatu komunitas, yang berdasar koneksi internet. Dimana pengguna perlu membuat sebuah profil atau akun yang berisi data pribadi dari pengguna. Isi data pribadi ini nantinya dapat ditunjukkan semuanya atau sebagian saja kepada pengguna yang lain. Pengguna juga dapat saling berbagi konten antar para pengguna dalam system serta dapat mengatur siapa yang akan menjadi teman dari pengguna situs tersebut. Facebook sebagai salah satu situs jejaring sosial yang popular, mempunyai nilai tersendiri bagi para penggunanya.

\subsection{Radikalisme}

Radikal berasal dari bahasa latin radix yang artinya akar. Dalam bahasa Inggris kata radical dapat bermakna ekstrim, menyeluruh, fanatik, revolusioner, ultra dan fundamental. Sedangkan radicalism artinya doktrin atau praktik penganut paham radikal atau paham ekstrim (Nuhrison, 2009). Dalam Kamus Besar Bahasa Indonesia, radikalisme diartikan sebagai paham atau aliran yang menginginkan perubahan dengan cara keras atau drastis. Sementara Sartono Kartodirdjo (1985) mengartikan radikalisme sebagai gerakan sosial yang menolak secara menyeluruh tertib sosial yang sedang berlangsung dan ditandai oleh kejengkelan moral yang kuat untuk menentang dan bermusuhan dengan kaum yang memiliki hak-hak istimewa dan yang berkuasa.

Radikalisme sering dimaknai berbeda diantara kelompok kepentingan. Dalam lingkup keagamaan, radikalisme merupakan gerakan-gerakan keagamaan yang berusaha merombak secara total tatanan sosial dan politik yang ada dengan jalan menggunakan kekerasan. Sedangkan dalam 
studi ilmu sosial, radikalisme diartikan sebagai pandangan yang ingin melakukan perubahan yang mendasar sesuai dengan interpretasinya terhadap realitas social atau ideologi yang dianutnya.

Dengan demikian, radikalisme merupakan gejala umum yang bisa terjadi dalam suatu masyarakat dengan motif beragam, baik sosial, politik, budaya maupun agama, yang ditandai oleh tindakantindakan keras, ekstrim, dan anarkis sebagai wujud penolakan terhadap gejala yang dihadapi. Dari berbagai pengertian di atas, dapat disimpulkan bahwa yang dimaksud dengan radikal bila dilihat dari pemahaman agama, dan yang kami maksud dalam tesis ini adalah agama Islam, adalah gerakan yang berpandangan kolot dan sering menggunakan kekerasan dalam mengajarkan keyakinan mereka. Sementara Islam merupakan agama kedamaian yang mengajarkan sikap damai dan mencari kedamaian. Islam tidak pernah membenarkan praktek penggunaan kekerasan dalam menyebarkan agama, paham keagamaan serta paham politik.

Radikalisme kelompok radikal memiliki ciri-ciri antara lain; pertama sering mengklaim kebenaran tunggal dan menyesatkan kelompok lain yang tak sependapat. Klaim kebenaran tidak dapat dibenarkan karena manusia hanya memiliki kebenaran yang relatif dan hanya Allah yang tahu kebenaran absolut. Kedua, radikalisme dicirikan dengan perilaku beragama yang lebih memprioritaskan persoalan-persoalan sekunder dan mengesampingkan yang primer. Ketiga, kelompok radikal kebanyakan berlebihan dalam beragama yang tidak pada tempatnya. Keempat, kasar dalam berinteraksi, keras dalam berbicara dan emosional dalam berdakwah. Kelima, kelompok radikal mudah berburuk sangka kepada orang lain di luar golongannya. Mereka senantiasa memandang orang lain hanya dari aspek negatifnya dan mengabaikan aspek positifnya. Keenam, mudah mengkafirkan orang lain yang berbeda pendapat. Irwan Masduqi, 2012:3.

\section{Metode Penelitian}

Metode penelitian merupakan metode untuk menentukan kebenaran yang merupakan sebuah pemikiran yang kritis. Penelitian mempunyai tujuan dan kegunaan tertentu. Melalui penelitian manusia dapat memanfaatkan hasil penelitiannya, secara umum data yang diperoleh dari penelitian dapat digunakan untuk memahami, memecahkan, dan mengantisipasi masalah.

Penelitian ini merupakan penelitian deskriptif dengan metode survey. Metode tersebut dipakai guna menganalisis pengaruh penyebaran informasi pada media social yang meningkatkan radikalisme yang dapat mengikis nilai-nilai kebangsaan. Data primer yang diperlukan diperoleh dari hasil pengamatan, wawancara dan kuesioner terstruktur kepada masyarakat yang akan dijadikan informan.

Dalam penelitian ini peneliti menggunakan Facebook sebagai objek penelitian dikarenakan di antara situs jejaring sosial lainnya, Facebook merupakan situs jejaring sosial yang paling popular.

\subsection{Teknik Pengumpulan Data}


Pengumpulan data primer akan dilakukan dengan kuisioner dan observasi. Sedangkan data sekunder akan didapatkan dari wawancara dan focus grup discussion.

\subsection{Metode Analisis Data}

Adapun metode analisis yang digunakan guna mencapai tujuan penelitian ini adalah untuk mengetahui analisis media social dalam penyebaran informasi pada media sosial yang mengancam nilai nilai kebangsaan dengan menggunakan analisis deskriptif berdasarkan pengamatan dan kajian pustaka

\section{Hasil Penelitian}

\section{Analisis Penyebaran Informasi}

Globalisasi tampak deras menerpa masyarakat Indonesia dengan kehadiran media sosial. Media tersebut membuka kesempatan kepada para penggunanya untuk dapat membagi apa saja yang pengguna pikirkan. Keterbukaan ini disikapi secara tidak dewasa oleh sebagian masyarakat, mereka sengaja ataupun tidak sengaja membagi semua informasi yang mereka punya, dari informasi pribadi, agama, sosial, politik, etnis dan lain sebagainya. Penyebaran informasi ini menimbulkan sikap yang beragam dari masyarakat. Sebagian informasi tersebut menimbulkan gesekan ekstrim di masyarakat hingga muncul gerakan-gerakan ekstrim atau gerakan radikal.

Penyebaran informasi dapat dianalisis dengan Teori Spiral Keheningan. Asumsi dari model ini adalah semakin sering media sosial mengemukakan pendapat yang dominan di kalangan masyarakat, semakin memudar atau melemah pendapat-pendapat di kalangan masyarakat yang menentang pendapat dominan sebagaimana dikemukakan media tersebut. Jumlah orang yang secara terbuka menentang pendapat dominan yang dikemukakan media sosial akan semakin mengecil. Dengan kata lain, suara-suara yang menentang akan semakin hening. Asumsi ini didasarkan pada pertimbangan bahwa pada dasarnya, kebanyakan orang dalam masyarakat cenderung tidak mau mengisolasikan dirinya dari lingkungan masyarakat di sekitarnya. Oleh karena itu, biarpun seseorang punya sikap atau pendapat yang berlainan, ia akan berusaha untuk tidak menentang secara terbuka sikap dan pendapat orang-orang lain di lingkungan sekitarnya (Nurudin, 2012)

MUNCUL OPINI/ ISU MENYEBAR DALAM MEDIA SOSIAL

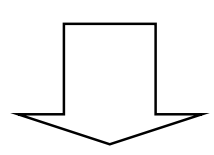

Keinginan untuk menyampaikan opini dalam status facebook 


\begin{tabular}{|l|}
\hline Media sosial \\
memberikan \\
opini yang \\
muncul dengan \\
dominan \\
\hline
\end{tabular}

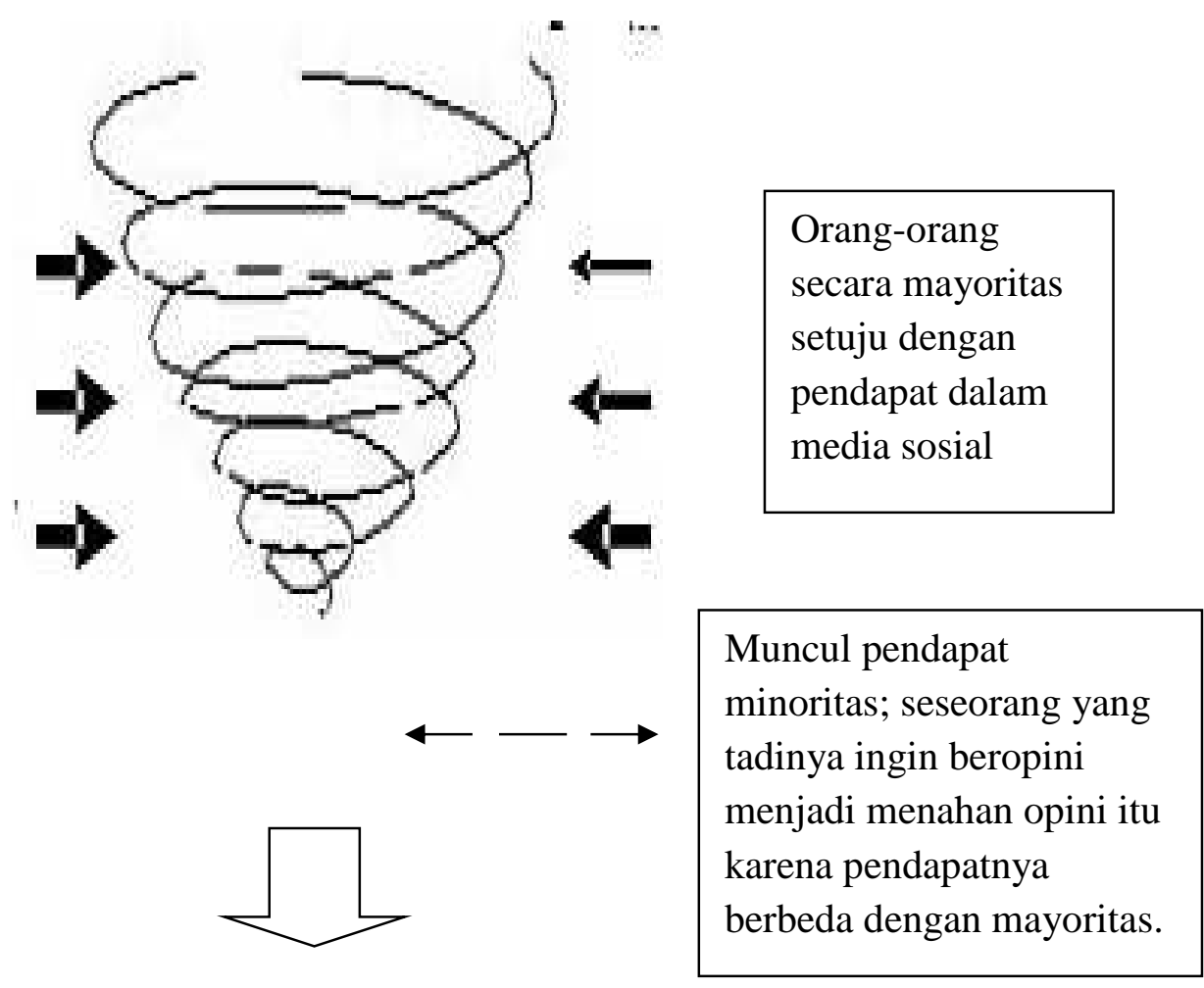

PENDAPAT MINORITAS : KETAKUTAN AKAN TERISOLASI

Gambar 2. Analisis Teori Keheningan

Berdasarkan analisa diatas, jika kita terapkan dalam konteks sekarang, dapat kita lihat bagaimana penyebaran ujaran kebencian ataupun berita bohong ataupun pemasaran produk tertentu dapat dominan dan mengalahkan berbagai opini lainnya tergantung banyak atau tidaknya opini individu yang ikut mendukung hal yang dominan tersebut.

Sehingga sebagai individu yang berpegang pada nilai kebenaran ataupun nilai kebangsaan haruslah tetap menyampaikan pendapat dalam media sosial agar penyebaran informasi tersebut dapat berimbang atau bahkan meminimalkan opini yang negatif. Tetapi sebagai warna negara yang baik kita juga harus melihat kebijakan yang berlaku di negara kita.

Negara mengatur penyebaran informasi elektronik tersebut dalam Undang-undang Informasi dan Transaksi Elektronik. Informasi Elektronik adalah satu atau sekumpulan data elektronik, termasuk tetapi tidak terbatas pada tulisan, suara, gambar, peta, rancangan, foto, electronic data interchange (EDI), surat elektronik (electronic mail), telegram, teleks, telecopy atau sejenisnya, huruf, tanda, angka, Kode Akses, simbol, atau perforasi yang telah diolah yang memiliki arti atau dapat dipahami oleh orang yang mampu memahaminya (UU ITE)

Karakteristik virtualitas ruang siber memungkinkan konten ilegal seperti Informasi dan/atau Dokumen Elektronik yang memiliki muatan yang melanggar kesusilaan, perjudian, penghinaan atau pencemaran nama baik, pemerasan dan/atau pengancaman, penyebaran berita bohong dan menyesatkan sehingga mengakibatkan kerugian konsumen dalam Transaksi Elektronik, serta perbuatan menyebarkan kebencian atau permusuhan berdasarkan suku, agama, ras, dan golongan, dan pengiriman ancaman 
kekerasan atau menakut-nakuti yang ditujukan secara pribadi dapat diakses, didistribusikan, ditransmisikan, disalin, disimpan untuk didiseminasi kembali dari mana saja dan kapan saja.

Dalam rangka melindungi kepentingan umum dari segala jenis gangguan sebagai akibat penyalahgunaan Informasi Elektronik dan Transaksi Elektronik, diperlukan penegasan peran Pemerintah dalam mencegah penyebarluasan konten ilegal dengan melakukan tindakan pemutusan akses terhadap Informasi Elektronik dan/atau Dokumen Elektronik yang memiliki muatan yang melanggar hukum agar tidak dapat diakses dari yurisdiksi Indonesia serta dibutuhkan kewenangan bagi penyidik untuk meminta informasi yang terdapat dalam Penyelenggara Sistem Elektronik untuk kepentingan penegakan hukum tindak pidana di bidang Teknologi Informasi dan Transaksi Elektronik.

penggunaan setiap informasi melalui media atau Sistem Elektronik yang menyangkut data pribadi seseorang harus dilakukan atas persetujuan Orang yang bersangkutan. Untuk itu, dibutuhkan jaminan pemenuhan perlindungan diri pribadi dengan mewajibkan setiap Penyelenggara Sistem Elektronik untuk menghapus Informasi Elektronik dan/atau Dokumen Elektronik yang tidak relevan yang berada di bawah kendalinya atas permintaan Orang yang bersangkutan berdasarkan penetapan pengadilan.

Berdasarkan pertimbangan tersebut, perlu membentuk Undang- Undang tentang Perubahan atas Undang-Undang Nomor 11 Tahun 2008 tentang Informasi dan Transaksi Elektronik yang menegaskan kembali ketentuan keberadaan Informasi Elektronik dan/atau Dokumen Elektronik dalam Penjelasan Pasal 5, menambah ketentuan kewajiban penghapusan Informasi Elektronik dan/atau Dokumen Elektronik yang tidak relevan dalam Pasal 26, mengubah ketentuan Pasal 31 ayat (4) mengenai pendelegasian penyusunan tata cara intersepsi ke dalam undang-undang, menambah peran Pemerintah dalam melakukan pencegahan penyebarluasan dan penggunaan Informasi Elektronik dan/atau Dokumen Elektronik yang memiliki muatan yang dilarang dalam Pasal 40, mengubah beberapa ketentuan mengenai penyidikan yang terkait dengan dugaan tindak pidana di bidang Teknologi Informasi dan Transaksi Elektronik dalam Pasal 43, dan menambah penjelasan Pasal 27 ayat (1), ayat (3), dan ayat (4) agar lebih harmonis dengan sistem hukum pidana materiil yang diatur di Indonesia.

Untuk membantu Pemerintah memberantas penyebaran berita palsu (hoax) dan ujaran kebencian bermuatan suku, agama, ras, dan antargolongan (SARA) yang berpotensi sebagai sumber perpecahan bangsa, Badan Kepegawaian Negara (BKN) menegaskan bahwa Aparatur Sipil Negara (ASN) diminta menjalankan fungsinya sebagai perekat dan pemersatu bangsa sebagaimana diamanatkan dalam UndangUndang Nomor 5 Tahun 2014 tentang ASN. Hingga siaran pers ini diterbitkan BKN telah menerima pengaduan dari masyarakat atas keterlibatan ASN dalam ragam aktivitas ujaran kebencian yang turut memperkeruh situasi bangsa. ASN yang terbukti menyebarluaskan ujaran kebencian dan berita palsu masuk dalam kategori pelanggaran disiplin. Mengantisipasi hal tersebut, BKN akan melayangkan imbauan bagi Pejabat Pembina Kepegawaian (PPK) Instansi Pusat dan Daerah untuk melarang ASN di lingkungannya menyampaikan dan menyebarkan berita berisi ujaran kebencian perihal SARA, serta mengarahkan ASN agar tetap menjaga integritas, loyalitas, dan berpegang pada empat pilar kebangsaan, 
yaitu Pancasila, Undang-Undang Dasar Republik Indonesia Tahun 1945, Bhinneka Tunggal Ika, dan Negara Kesatuan Republik Indonesia (NKRI).

Berikut bentuk aktivitas ujaran kebencian yang masuk dalam kategori pelanggaran disiplin:

1. Menyampaikan pendapat baik lisan maupun tertulis lewat media sosial yang bermuatan ujaran kebencian terhadap Pancasila, Undang-Undang Dasar Republik Indonesia Tahun 1945, Bhinneka Tunggal Ika, NKRI, dan Pemerintah

2. Menyampaikan pendapat baik lisan maupun tertulis lewat media sosial yang mengandung ujaran kebencian terhadap salah satu suku, agama, ras, dan antargolongan 3. Menyebarluaskan pendapat yang bermuatan ujaran kebencian (pada poin 1 dan 2) melalui media sosial (share, broadcast, upload, retweet, repost Instagram dan sejenisnya) 4. Mengadakan kegiatan yang mengarah pada perbuatan menghina, menghasut, memprovokasi, dan membenci Pancasila, Undang-Undang Dasar Republik Indonesia Tahun 1945, Bhinneka Tunggal Ika, NKRI, dan Pemerintah 5. Mengikuti atau menghadiri kegiatan yang mengarah pada perbuatan menghina, menghasut, memprovokasi, dan membenci Pancasila, Undang-Undang Dasar Republik Indonesia Tahun 1945, Bhinneka Tunggal Ika, NKRI, dan Pemerintah 6. Menanggapi atau mendukung sebagai tanda setuju pendapat sebagaimana pada poin 1 dan 2 dengan memberikan like, dislike, love, retweet, atau comment di media sosial.

\section{Simpulan}

Penyebaran informasi pada media sosial akan semakin dominan jika semakin sering media sosial mengemukakan pendapat yang dominan di kalangan masyarakat maka semakin memudar atau melemah pendapat-pendapat di kalangan masyarakat yang menentang pendapat dominan.

\section{Daftar Pustaka}

Asrori, Ahmad. 2017 "Radikalisme di Indonesia: Antara Historisitas dan Antropisitas". dalam Http://Ejournal.Radenintan.Ac.Id/Index.Php/Kalam/Article/View/331. diunduh 1 Juni 2017

Budiharso, Suyuti S. 2003. Politik Komunikasi. Jakarta: Grasindo.

Calhoun, Craig. 2012. The Roots of Radicalism: Tradition, the Public Sphere and Early NineteenthCentury Social Movements. University of Chigago Press

Crelinsten, Ronald. 2009. Counterterrorism. Polity USA: Bloomsbury.

Curran, James. 2000. "Mass Media and Democacry: A Reappraiusal". dalam Curran, James dan Michael Gurevitch (eds). Mass Media and Society. Third edition. New York; Edward Arnold.

Departemen Pendidikan dan Kebudayaan. 1990. Kamus Besar Bahasa Indonesia (Jakarta: Balai Pustaka, 354. 
Hasani, Ismail dan Bonar Tigor Naipospos, 2010. Radikalisme Agama di Jabodetabek \& Jawa Barat: Implikasinya terhadap Jaminan Kebebasan Beragamal Berkeyakinan. Jakarta: Pustaka Masyarakat Setara: 19.

Hoffman, Bruce. 2006. Inside Terrorism. Jewkes: University of Columbia Press.

Hornby, A.S. 2000. Oxford Advenced, Dictionary of Current English. UK: Oxford University Press Http://Www.Kompasiana.Com/Anggit28/Media-Sosial-Paling-Banyak-Digunakan2016_586f082cd07a61750511493c

Http://Www.Kompasiana.Com/Anggit28/Media-Sosial-Paling-Banyak-Digunakan2016_586f082cd07a61750511493c

Http://Www.Kompasiana.Com/Bimabela.Com/Empat-Langkah-Merawat-Kerukunan-Beragama-PadaEra-Media-Sosial_57d29178317a617e56e976f7

Irwan Masduqi, 2012. "Deradikalisasi Pendidikan Islam Berbasis Khazanah Pesantren” dalam Jurnal Pendidikan Islam, No 2 Vol 1, 2012), 3. Dalam http://digilib.uinsby.ac.id/14320/5/Bab\%202.pdf

Kartodirdjo, Sartono. 1985. Ratu Adil. Jakarta: Sinar Harapan

Koentjoro \& Rubianto, Beben. 2009. Radikalisme Islam dan Perilaku Orang Kalah dalam Perspektif Psikologi Sosial. Psikobuana, 1(1). 64-70

Miles, M.B \& Hubermen, A.M. 1994. Qualitative Data Analysis: A Sourcebook of New Methods. London: Sage Publications, in Punch. 2005. Introduction to Social Research, Quantitative, and Qualitative Approaches. Sage Publication Ltd.

Muthohirin, Nafi'. 2017. "Radikalisme Islam dan Pergerakannya di Media Sosial" Http://Journal.Umy.Ac.Id/Index.Php/Afkaruna/Article/View/2211/2148 diunduh 02 Juni

Nacos, Brigitte L. 2007. Mass-Mediated Terrorism, The Central Role of The Media in Terrorism and Counterterrorism. Rowman \& Littlefield Publisher, Inc.

Nuhrison, M. Nuh, 2009. "Faktor-Faktor Penyebab Munculnya Faham/ Gerakan Islam Radikal di Indonesi” HARMONI Jurnal Multikultural \& Multireligius, Vol VIII Juli-September 2009), 36.

Nurudin. 2012. Pengantar Komunikasi Massa. Jakarta : Rajawali Pers

Rakhmat, Jalaluddin. 2004. Psikologi Komunikasi. PT. Remaja Rosdakarya: Bandung.

Rubaidi, A. 2007. Radikalisme Islam, Nahdatul Ulama Masa depan Moderatisme Islam di Indonesia. Yogyakarta: Logung Pustaka.

Simut, Corneliu C. 2010. Traditionalism and Radicalism in the History of Christian Thought. Palgrave Macmillan

Timmerman, Christian. (Ed.) 2009. Faith-based Radicalism: Christianity, Islam, and Judaism Between Constructive Activism and Destructive Fanaticism. Peter Lang International Academic Publisher

Umar, Ahmad Rizky Mardhatillah. 2010. "Melacak Akar Radikalisme Islam di Indonesia" dalam Jurnal Ilmu Sosial dan Ilmu Politik Volume 14, Nomor 2, November 2010 (169-186) Issn 1410-4946 
Wiktorowicz, Quintan. (Ed.). 2003. Islamic Activism: A Social Movement Theory Approach (Indiana Series In Middle East Studies). USA: Indiana University Press.

Winarni, Leni. 2014. "Media Massa dan Isu Radikalisme Islam”. dalam Jurnal Komunikasi Massa Vol. 7 No. 2, Juli 2014: 159-166

Yvonne. 2011. Media \& Crime (2 ${ }^{\text {th }}$ ed.). Sage Publication Ltd. 